\title{
Sanctions Towards the Treasurers of Government Amil Zakat Agency in Pagaralam City, Indonesia
}

\author{
Fitria Kusumawardhani \\ Faculty of Law, Universitas Lancang Kuning, Indonesia. \\ E-mail : fitriakusumawardhani@rocketmail.com
}

How to cite : Fitria Kusumawardhani. (2019). Sanctions Towards the Treasurers of Government Amil Zakat Agency in Pagaralam, Indonesia. UNIFIKASI : Jurnal IImu Hukum, 6(1), 14-22. DOI : 10.25134/unifikasi.v6i1.1435

Submitted : 24-10-2018 Revised : 31-05-2019 Accepted : 10-06-2019

\begin{abstract}
This study aims to identify and analyze the imposition of sanctions on the government treasurers of Amil Zakat Agency in Pagaralam City, Indonesia. Law No. 20 of 2011 concerning the Eradication of Criminal Acts of Corruption, theory of zakat, agreement between the Treasurer and the Amil Zakat Agency as well as Regulation of the Finance and Development Supervisory Agency were employed in this study. This study applied a normative juridical approach that is a legal systematic approach identifying the core of law. The objects of this study include; $a$. Legal Subject; b. Rights and obligations; and c. Legal events in legislations. The collected data were then analyzed qualitatively. The results indicated that there was embezzlement of funds carried out by the government treasurers of Amil Zakat Agency on zakat funds which should be used for people who need financial assistance and which should be used to empower low-socio economic community groups.
\end{abstract}

Keywords: Imposition of Sanctions; Corruption; Zakat Fund; Treasurer; Amil Zakat Agency.

\section{Sanksi terhadap Bendahara Badan Amil Zakat Pemerintah di Kota Pagaralam, Indonesia}

\begin{abstract}
Abstrak : Pancasila adalah hasil konsensus bersama para pendiri bangsa Indonesia. Pancasila sebagai ideologi dan pandangan hidup bangsa memberikan arah dan tujuan untuk membangun masyarakat Indonesia yang adil dan makmur dalam NKRI. Tujuan penelitian ini adalah bagaimana Aksiologi Pancasila dalam Rekonstruksi Budaya Hukum Di Indonesia. Metode penelitian yang digunakan dalam penelitian ini adalah yuridis normatif. Hasil penelitian yaitu Pancasila tercantum dalam Pembukaan UUD 1945 sebagai konsitusi Negara yang perlu diaktualisasikan dalam kehidupan sehari-hari. Sehingga memberikan konsekuensi, bahwa nilai-nilai Pancasila sebagai hasil kristalisasi budaya bangsa yang bersifat multikulturalisme harus tercermin dalam pola pikir, cipta rasa dan tingkah laku masyarakat Indonesia. Dalam bidang hukum, nilai-nilai Pancasila harus tercermin dalam penegakan hukum yang berwatak rasa keadilan sosial bagi seluruh rakyat Indonesia. Sehingga budaya hukum yang berkarakter nilai-nilai Pancasila perlu diaktualisasikan demi terwujudya kesadaran hukum nasional dalam upaya membangun hukum yang mengayomi dan memberikan rasa keadilan bagi seluruh rakyat Indonesia.
\end{abstract}

Kata Kunci: Nilai Pancasila, Nilai, dan Budaya Hukum

\section{INTRODUCTION}

National law applies to all Indonesian people. One form of national law is the National Amil Zakat Agency (BAZNAS) as a national institution managing zakat. BAZNAS is a non-structural institution that is independent and is responsible to the President through the Minister of Religious Affairs. Any institutions or agencies owned by the Central Government and Regional Governments running businesses or carrying out activities to earn income are subject to tax. Therefore, their businesses must be under the supervision of the Finane and Development Supervisory Agency to prevent criminal acts of corruption. The subject of law itself is anything that can obtain rights and obligations from law.

Pancasila contains principles reflecting the willpower and aspirations of the Indonesian nation. Those principles include: ${ }^{1}$

\footnotetext{
${ }^{1}$ Warkum Sumitro, Legislasi : Hukum Islam Transformatif, 2015, Malang : Setara Press, p. 42
} 
1. The principle of divinity mandates there should not be national legal products that are contrary or are opposed to or conflict to religion.

2. The principle of humanity mandates the law must protect citizens and uphold human dignity.

3. The principle of unity or nationality mandates national law applies/functions to all citizens.

4. The principle of democracy mandates in the relationship between law and power, power must obey the law and not the other way.

5. The principle of social justice mandates all citizens have the same rights and are equal before the law.

As previously mentioned, the principle of unity or nationality mandates national law applies/functions to all citizens. One form of national law is the National Amil Zakat Agency (BAZNAS) as a national institution managing zakat. BAZNAS is a non-structural institution that is independent and is responsible to the President through the Minister of Religious Affairs. Any institutions or agencies owned by the Central Government and Regional Governments running businesses or carrying out activities to earn income are subject to tax.

Humans relation with God can be seen from the fulfillment of religious obligations, such as prayer, zakat, fasting, etc., as mentioned in the Qur'an: ${ }^{2}$

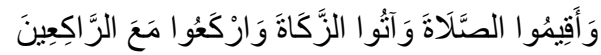

Meaning: "And establish prayer and give zakat and bow with those who bow [in worship and obedience]". (QS. Al-Baqarah: 43).

In the book of fiqh, giving is infak, zakat and alms. Imam Asy-Sharkhasyi al Hanafi, in his book "Al Mabsuth" says that in terms of its terminology "zakat" means growing and increasing. It is called "zakat" because it is the reason for the increase in wealth which Allah ta'ala replaced in the world and the rewards in the hereafter, as mentioned in the Qur'an:

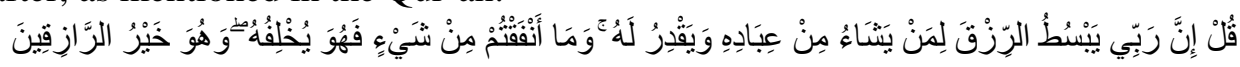

Meaning: "Indeed, my Lord extends provision for whom He wills of His servants and restricts [it] for him. But whatever thing you spend [in His cause], He will compensate it; and He is the best of providers" (QS. Saba: 39).

Hamidy Thalib, Muhammad Irwan and Ihsan Ro'is, as cited in Azani (2017), have analyzed the model of zakat management to overcome poverty in Bima City. Their study revealed that there are two ways of zakat management done by the Amil Zakat Agency in Bima City including zakat management that is in accordance with Islamic principles and is not in accordance with Islamic principles in which the Amil Zakat Agency does not coordinate with other parties in distributing zakat and does not publish reports on zakat management to the local community. ${ }^{3}$ Moreover, in Achmat Subekan's study, it is stated that zakat allocation is also intended for equal distribution of development to realize public welfare. The disbursement of funds from the State Treasury Account is carried out by each ministry/agency (budget user) by issuing a Payment Order (SPM) to the Minister of Finance as the State General Treasurer (State Treasury Account Holder). ${ }^{4}$

Government Treasurer is an employee appointed by the government to pay for goods and services expenditure as well as capital issued by the government to government partners in which its funds come from APBN, APBD and other sources. Government Treasurers are subject to tax and zakat, but they are quite different from corporate and individual taxpayers. ${ }^{5}$ Government Treasurers consist of Central Government Treasurer, Regional Government Treasurer and Village Treasurer.

\footnotetext{
${ }^{2}$ Drs. Dalizar Putra, Hak Asasi Manusia Menurut Al-Qur'an, 1995, Jakarta : PT. Al-Husna Zikra. p. 17

3 Muhammad Azani, Jurnal Pendayagunaan Zakat di Badan Amil Zakat Nasional Kota Pekanbaru Berdasarkan Undang-Undang Nomor 23 Tahun 2011 tentang Pengelolaan Zakat,Pekanbaru, 2017, p. 5.

${ }^{4}$ Achmat Subekan, Jurnal Potensi Zakat Menjadi Bagian Keuangan Negara, 2016, Balai Diklat Keuangan Malang, p. 9.

Wibowo Pajak, Artikel Pajak untuk Bendahara Pemerintah, http://www.wibowopajak.com/2012/01/pajak-untuk-bendahara-pemerintah.html, 2018
} 
The central point of Islamic legislative body theory is shura. This term is mentioned once in the Qur'an. Islamic political thinkers use the word shura as the normative basis for the theory of Islamic legislative body. Basically, there are several definitions of shura provided by some Muslim thinkers. First, shura is defined as asking for opinions from experts to take policies that are close to the truth. Second, shura is defined as asking for opinions from the people or those who represent it in matters relating to public interests. Third, shura is defined as a medium for community participation in the exchange of opinions in making public policy. ${ }^{6}$ The subject of law is anything that can obtain rights and obligations from law. Humans or something that can be likened to someone we often know by the term of legal entities are the ones that can get the rights and obligations from law. Some official institutions established based on regulations are: 1) National Amil Zakat Agency (BAZNAS); 2) Amil Zakat Institution (LAZ); and 3) Zakat Collection Unit (UPZ).

In terms of agreement, every two-sided legal act is an agreement (oovereenkomst). State-owned enterprises and regional-owned enterprises are subject to tax without regard to their names and forms. Thus, each unit of government agency, for example institutions, entities, etc., owned by the Central Government and Regional Governments running businesses or carrying out activities to earn income is subject to tax. This regulation also applies to all associations, unions, organizations or any ties of parties who have same interests, not exception to the National Amil Zakat Agency (BAZNAS). The Amil Zakat Agency (BAZ) consists of 8 (eight) people from the community and 3 (three) people from the government. This agency has the authority to collect, distribute and utilize zakat in Province and District/City. Yet, the Treasurers of Amil Zakat Agency (BAZ) in Pagaralam City were proved committing criminal acts of corruption. ${ }^{7}$ Based on the description, the problem discussed in this study is formulated into the following questions: What is the agreement between the Amil Zakat Agency and the Government Treasurer? and What are the sanctions imposed to the government treasurers of Amil Zakat Agency committing criminal acts of corruption in Pagaralam City?

\section{RESEARCH METHODS}

This study employed a normative juridical approach that is a legal systematic approach identifying the core of law. The objects of this study include; a. Legal Subject; b. Rights and obligations; and c. Legal events in legislations. Law No. 20 of 2011 concerning the Eradication of Criminal Acts of Corruption, theory of zakat, agreement between the Treasurer and the Amil Zakat Agency as well as Regulation of the Finance and Development Supervisory Agency were used in this study. The collected data were then analyzed qualitatively.

\section{RESULTS AND DISCUSSION}

\section{Agreement between the Amil Zakat Agency and the Government Treasurer}

Zakat is one of the pillars of Islam. Its position is the same as creed, prayer, fasting and Hajj. Rasulullah said: "Islam is built on five pillars. To confess that no one has the right to be worshiped except Allah and the Prophet Muhammad is a messenger of Allah, to establish prayer, to give zakat, to carry out fasting in the month of Ramadan and to go to the Baitullah." (Narrated by Al-Bukhari No. 8 and Muslims No. 16 from Abdullah bin 'Umar). The distribution of Zakat on the object of Zakat of Profession is:

1. Gross income - the income received from reaching reckoning 85 grams of gold in one year, $2.5 \%$ of his zakat is directly issued when receiving before conducting any deduction.

\footnotetext{
${ }^{6}$ Warkum Sumitro, Legislasi : Hukum Islam Transformaitif, Op. Cit, p. 39.

${ }^{7}$ Sriwijaya Pos, Empat Bendahara Gaji di Pemkot Pagaralam Terbukti Korupsi Divonis Satu hingga Tiga Tahun Penjara, palembang.tribunews, 2017 Retrieved on 11 September 2018
} 
2. Net income - giving zakat from income received after deducting basic needs, paying debts, and the needs of himself, his family and his dependents. If the net income still reaches 85 grams of gold in one year, then he is obligatory to give zakat. Yet, if the net income does not reach nishab, he is not obligatory to give Zakat.

3. Income minus operating costs - income received minus work operational costs (such as transportation, daily needs at work, work equipment costs, etc.). If his income reaches nishab, worth 85 grams of gold in one year, he is obligatory to give zakat. These operational costs are qiyas with zakat made from nummies and date palm fruits.

Zakat of Profession is a new thing in the grouping of assets that must be issued zakat. The term profession is translated into Arabic with two words: First, the word al-mihnah which is used to express work that relies more on the brain. Therefore, professionals are called al-mihaniyyun or ashab al-minah, for example doctors, lawyers, writers, legal consultants, artists, etc. Second, work that is tied to other parties (Kasb al'amal), namely people who carry out their work through a contract or agreement with other parties, for example civil servants, military, police, factory employees and company employees or work as an individual employee who receives a regular income every month (Fiqh of Islam Wa Adillatuhu, Juzz 2 pages 865-866). People who have job with a fixed salary or have something that they rents such as a house are not obliged to give zakat if they do not save money from their rent or salary. Meanwhile, if they save money from their rent or salary, they must give zakat.

Giving zakat of profession in gold or trade must be worth 85 grams of pure gold. The zakat is determined $2.5 \%$ considering haul and all income in that year with the assumption that zakat is an obligation charged to its value (al-qimah), not to its material (al-ain). The payment can be made at the end of the year ( $\mathrm{haul}$ ) or in instalments on each time receiving salary or professional results (Fiqh alzakat, 1/59-520). If zakat of profession is paid with crops, the nishab must be worth $653 \mathrm{~kg}$ of rice and zakat $5 \%$ is paid when receiving salary or professional results. Zakat of profession can also be paid without following the nishab and year, that is, at the time the salary is received.

Every legal relationship has two aspects, namely right (authority or bevoegdheid) and obligation (plicht). This right is given by law to someone or a legal entity because of its legal relationship with another person or a legal entity. Law as a set of regulations governing social relations give someone or a legal entity the rights, namely the authority to do something, to sue someone or a legal entity, etc. In this case, the authority to collect zakat is owned by Government General Treasurer. Collecting zakat aims to prosper the community's economy through the $2.5 \%$ of the salaries earned by civil servants each month. A one-sided legal act is any action that has legal consequences (rechtsgelog) in which its consequences are caused by the will of one legal subject, that is, one party (who has committed the act). Meanwhile, a two-sided legal act is any action that results from the law caused by the will of two legal subjects, that is, an act which causes one person or more binding himself to someone (legal subject). Thus, every two-sided legal act is an agreement (oovereenkomst). State-owned enterprises and regionalowned enterprises are subject to tax without regard to their names and forms. Thus, each unit of government agency, for example institutions, entities, etc., owned by the Central Government and Regional Governments running businesses or carrying out activities to earn income is subject to tax. This regulation also applies to all associations, unions, organizations or any ties of parties who have same interests. ${ }^{8}$

National Amil Zakat Agency (BAZNAS), based on Article 6 of Law No. 23 of 2011 concerning Management of Zakat, is a national institution authorized to carry out the task of managing zakat. In carrying out its tasks, as regulated in Article 6, BAZNAS has the functions of: a) planning the collection, distribution and utilization of zakat; b) implementing the collection, distribution and

${ }^{8}$ Ahmadi Miru, 2008, Hukum Perikatan : Penjelasan Makna Pasal 1233 sampai 1456 BW, (Jakarta : Rajawali Press), p. 74 
utilization of zakat; c) controlling the collection, distribution and utilization of zakat, and d) reporting the zakat management result. Regulation of the Minister of Religious Affairs of the Republic of Indonesia No. 18 of 2016 concerning Organization and Work Procedure of the Secretariat of National Amil Zakat Agency describes that BAZNAS has the functions of:

a. coordinating the preparation of work programs, activities and budgets;

b. collecting information and developing information system;

c. formulating regulation and legal advocacy;

d. carrying out financial affairs;

e. carrying out organization, cooperation and public relations;

f. managing staffing administration;

g. carrying out administrative affairs, such as equipment and property of the state at BAZNAS; and

h. evaluating and reporting zakat.

Based on the Regulation of the Minister of Finance No. 162/Pmk.05/2013 concerning Position and Responsibilities of Treasurer in a Work Unit of the National Budget Managers, Treasurer Accountability Report, hereinafter abbreviated as LPJ, is a report made by the Treasurer for the money he manages as the responsibility for managing the money. BPP is a person appointed to assist the treasurer to carry out payments in order to do certain activities. ${ }^{9}$ Presidential Regulation of the Republic of Indonesia No. 192 of 2014 concerning the Finance and Development Supervisory Agency (BPKP) states that by taking into account Law No. 30 of 2002 concerning the Corruption Eradication Commission, the approach taken by BPKP is directed to be more preventive and not entirely audit or repressive. Socialization, assistance and evaluation are activities that have begun to be done by BPKP. Meanwhile, investigative audits are carried out to assist law enforcement officials to calculate financial losses of the state. The formulation of national policy on internal control over state/regional financial accountability and national development includes cross-sectoral activities, general state treasury activities based on the regulations set by the Minister of Finance as the State General Treasurer, and other activities based on assignments from the President. ${ }^{10}$

\section{Imposition of Sanctions Against the Government Treasurers of Amil Zakat Agency in Pagaralam City, Indonesia}

The resort police of Pagaralam City arrested four suspects suspected of being involved in embezzlement of zakat funds. The case that has been signed by the resort police of Pagaralam City since 2014 finally named four suspects, namely Surimawati as the treasurer of Pagaralam City Civil Service Police Unit, Listianawati as the treasurer of North Pagaralam sub-district, Legimin as the treasurer of Public Works Agency, and Mukamin as the treasurer of Department of Animal Husbandry and Fisheries Service of Pagaralam City. After carrying out investigations, the resort police of Pagaralam City through the Corruption Action Unit (TIPIKOR) finally arrested four suspects who are suspected to embezzle BAZ funds in four Regional Work Units in Pagaralam City. Candra said that this criminal act was carried out by the suspects from 2004 to 2014. They had not deposited 2.5 percent of civil servant salaries to the Pagaralam City BAZ account. Thus, within a period of 13 years, based on the BPKP audit results, the state financial loss reached Rp. 659,025,311. The four suspects are subjected to Article 8 and 2 paragraph 1 and 2 of Law No. 31 of 1999 jo. Law No. 20 of 2011 concerning Eradication of Criminal Acts of Corruption by a minimum sentence of 5 (five) years.

\footnotetext{
${ }^{9}$ Peraturan Menteri Keuangan Nomor 162/PMK. 05/2013 Tentang Kedudukan dan Tanggung Jawab Bendahara pada Satuan Kerja Pengelola Anggaran Pendapatan dan Belanja Negara

10 Peraturan Presiden Republik Indonesia, Nomor 192 Tahun 2014 tentang Badan Pengawasan Keuangan dan Pembangunan
} 
The central point of Islamic legislative body theory is shura. This term is mentioned once in the Qur'an. Islamic political thinkers use the word shura as the normative basis for the theory of Islamic legislative body. Basically, there are several definitions of shura provided by some Muslim thinkers. First, shura is defined as asking for opinions from experts to take policies that are close to the truth. Second, shura is defined as asking for opinions from the people or those who represent it in matters relating to public interests. Third, shura is defined as a medium for community participation in the exchange of opinions in making public policy. ${ }^{11}$ The subject of law is anything that can obtain rights and obligations from law. Humans or something that can be likened to someone we often know by the term of legal entities are the ones that can get the rights and obligations from law. According to Law No. 36 of 2008 concerning Income Tax, tax subjects are: a) Individual person; b) An inheritance that has not been divided as a whole; and c) Legal entity. Elucidation of Article 2 (1) letter (a) state an individual as a tax subject can be in Indonesia or outside Indonesia. An inheritance that has not been divided as a whole is subject to tax replacing those entitled to the heirs. Further, Elucidation of Article 2 paragraph (1) letter (b) states legal entity is a group of people that constitutes an entity which includes limited liability company, state-owned enterprise or regional-owned enterprise, firms, partnerships, corporations, associations, unions, foundations, mass organizations, socio-political organizations, institutions and other forms of bodies including collective investment contracts.

State-owned enterprises and regional-owned enterprises are subject to tax without regard to their names and forms. Thus, each unit of government agency, for example institutions, entities, etc., owned by the Central Government and Regional Governments running businesses or carrying out activities to earn income is subject to tax. This regulation also applies to all associations, unions, organizations or any ties of parties who have same interests. According to Law No. 31 of 1999 jo. Law No. 20 of 2001, acts of corruption are classified into seven types, namely: bribes, gratuities, funds embezzlement, deprivation, conflicts of interest, and civil servants or state administrators who intend to benefit themselves. In the case of embezzlement of zakat funds in Pagaralam City, based on the BPKP audit results, it was found that this criminal act was carried out by the suspects from 2004 to 2014 . Thus, within a period of 13 years, the state financial loss reached Rp. 659,025,311. The four suspects are subjected to Article 2 paragraph (1) and paragraph (2) of Law No. 31 of 1999 and Article 8 of Law No. 20 of 2001 concerning Eradication of Criminal Acts of Corruption. This criminal act of corruption was carried out in groups by Surimawati as the treasurer of Pagaralam City Civil Service Police Unit, Listianawati as the treasurer of North Pagaralam sub-district, Legimin as the treasurer of Public Works Agency, and Mukamin as the treasurer of Department of Animal Husbandry and Fisheries Service of Pagaralam City. Therefore, it is appropriate if the state applies Article 8 in which the suspects are sentenced with imprisonment for a minimum of 3 (three) years and a maximum of 15 (fifteen) years and a minimum fine of Rp150,000,000.00 (one hundred fifty million rupiah) and a maximum of Rp750,000,000.00 (seven hundred and five tens of millions of rupiah).

A civil servant or anyone other than public servant assigned to carry out a public position deliberately embezzles money or securities that are kept for his position, or allows the money or securities to be taken or embezzled by others, or assists in carrying out the act is appropriate if the state applies Article 8 of Law No. 20 of 2001 concerning Eradication of Criminal Acts of Corruption in which it is states that the suspect shall be sentenced with imprisonment for a minimum of 3 (three) years and a maximum of 15 (fifteen) years and a minimum fine of Rp150,000,000.00 (one hundred fifty million rupiah) and a maximum of Rp750,000,000.00 (seven hundred and five tens of millions of rupiah). In order to provide legal certainty and protection to the social and economic rights of the community as well as fair treatment in eradicating corruption, the four Treasurers in Pagaralam City were sentenced to one or three years of prisons.

${ }^{11}$ Warkum Sumitro, Legislasi : Hukum Islam Transformaitif, Op. Cit, p. 39. 
The imposition of sanctions on the treasurers government of Amil Zakat Agency in Pagaralam City, Indonesia provides legal certainty and protection to the social and economic rights of the community as well as fair treatment in eradicating corruption. Based on Article 8 of Law No. 20 of 2001 concerning Eradication of Criminal Acts of Corruption, the imprisonment for a minimum of 3 (three) years and a maximum of 15 (fifteen) years and a minimum fine of Rp150,000,000.00 (one hundred fifty million rupiah) and a maximum of Rp750,000,000.00 (seven hundred and five tens of millions of rupiah) for a civil servant or anyone other than public servant assigned to carry out a public position deliberately embezzles money or securities that are kept for his position, or allows the money or securities to be taken or embezzled by others, or assists in carrying out the act is appropriate.

\section{CONCLUSION}

Agreement between the Amil Zakat Agency and the Government Treasurer, From the embezzlement case of zakat funds in Pagaralam city, the author can state that in the implementation phase, the parties must carry out what has been agreed to be their obligation in the agreement. If one party or even both parties do not carry out their obligations in accordance with the agreement, that is what is called a default. A one-sided legal act is any action that has legal consequences (rechtsgelog) in which its consequences are caused by the will of one legal subject, that is, one party (who has committed the act). Meanwhile, a two-sided legal act is any action that results from the law caused by the will of two legal subjects, that is, an act which causes one person or more binding himself to someone (legal subject). Thus, every two-sided legal act is an agreement (oovereenkomst). State-owned enterprises and regional-owned enterprises are subject to tax without regard to their names and forms. Thus, each unit of government agency, for example institutions, entities, etc., owned by the Central Government and Regional Governments running businesses or carrying out activities to earn income is subject to tax. This regulation also applies to all associations, unions, organizations or any ties of parties who have same interests.

Imposition of Sanctions Against Government Treasurers of Amil Zakat Agency in Pagaralam City, Indonesia, The imposition of sanctions on the treasurers government of Amil Zakat Agency in Pagaralam City, Indonesia provides legal certainty and protection to the social and economic rights of the community as well as fair treatment in eradicating corruption. Based on Article 8 of Law No. 20 of 2001 concerning Eradication of Criminal Acts of Corruption, the imprisonment for a minimum of 3 (three) years and a maximum of 15 (fifteen) years and a minimum fine of Rp150,000,000.00 (one hundred fifty million rupiah) and a maximum of Rp750,000,000.00 (seven hundred and five tens of millions of rupiah) for a civil servant or anyone other than public servant assigned to carry out a public position deliberately embezzles money or securities that are kept for his position, or allows the money or securities to be taken or embezzled by others, or assists in carrying out the act is appropriate. In this case, the four Treasurers in Pagaralam City were sentenced to one or three years of prisons.

\section{SUGGESTION}

The role of the Finance and Development Supervisory Agency (BPKP) is to formulate national policy on internal control over state/regional financial accountability and national development including cross-sectoral activities, general state treasury activities based on the regulations set by the Minister of Finance as the State General Treasurer, and other activities based on assignments from the President. The approach taken by BPKP is directed to be more preventive and not entirely audit or repressive. Socialization, assistance and evaluation are activities that have begun to be done by BPKP. Meanwhile, investigative audits are carried out to assist law enforcement officials to calculate financial losses of the state. Thus, the state's general treasury activities are monitored by being based on the regulations set by the Minister of Finance as the State General Treasurer. Some official institutions established based on regulations are: 1) National Amil Zakat Agency (BAZNAS); 2) Amil Zakat 
Institution (LAZ); and 3) Zakat Collection Unit (UPZ). Harmonization and coordination between sectors can advance the country's economy sourced from taxes collected every month from Government Treasurers in all Agencies. To avoid embezzlement of funds and fictitious data, the role of the Finance and Development Supervisory Agency (BPKP) is very important. It is because zakat is an important aspect in Islamic world so that everyone will be concerned on this issue.

\section{Books}

\section{REFERENCES}

Achmat Subakan,2016,Jurnal Potensi Zakat menjadi Bagian Keuangan Negara. Balai Diklat Keuangan:Malang

Ahmadi Miru,2008,Hukum Perikatan : Penjelasan Makna Pasal 1233 sampai 1456 BW, Rajawali Press: Jakarta

Dalizar Putra,1995, Hak Asasi Manusia Menurut Al-Qur'an. PT. Al-Husna Zikra : Jakarta

Gus Arifin, 2016, Keutamaan Zakat, Infak, Sedekah. PT Elex Media Komputindo, Kelompok Gramedia - Anggota IKAPI : Jakarta

Salim, 2013, Penerapan Teori Hukum pada Penelitian Tesis dan Disertasi, PT.Raja Grafindo Persada : Jakarta

Warkum Sumitro, 2015, Legislasi : Hukum Islam Transformaitif, Setara Press : Malang

\section{Journals}

Abdul Haris Romdhoni. 2017. "Zakat Dalam Mendorong Pertumbuhan Ekonomi Dan Pengentasan Kemiskinan”, Jurnal Ilmiah Ekonomi Islam, Volume 03. Nomor 01, Maret 2017

Abustan. 2017. "Relasi Lembaga Negara Dalam Perspektif Undang Undang Dasar Negara Republik Indonesia 1945". Unifikasi : Jurnal Ilmu Hukum, Vol. 04 Nomor 02 Juli 2017

Achmat Subekan. 2016. "Potensi Zakat Menjadi Bagian Keuangan Negara (Studi Analisis Regulasi Kemungkinan Masuknya Zakat Menjadi Bagian dari Penerimaan dan Pengeluaran Negara)" JURISDICTIE Jurnal Hukum dan Syariah. Volume 7 Nomor 2 Tahun 2016

Clarashinta Canggih, Khusnul Fikriyah, Ach. Yasin. 2017. "Potensi Dan Realisasi Dana Zakat Indonesia", al-Uqud: Journal of Islamic Economics, Volume 1 Nomor 1, Januari 2017

Haris Budiman dan Suwari Akhmaddhian, "Implementasi Reformasi Birokrasi Bidang Perizinan Pananaman Modal di Kabupaten Kuningan” Jurnal Unifikasi, ISSN 2354-5976 Vol. 1 No. 1 Oktober 2013.1-19.

Muhammad Azani. 2017. "Pendayagunaan Zakat di Badan Amil Zakat Nasional Kota Pekanbaru Berdasarkan Undang-Undang Nomor 23 Tahun 2011 tentang Pengelolaan Zakat”, Jurnal Hukum Respublica Volume 17 Nomor 1 Tahun 2017

N. Oneng Nurul Bariyah. 2016. "Dinamika Aspek Hukum Zakat Dan Wakaf Di Indonesia", Ahkam : Jurnal Ilmu Syariah, Volume XVI, Nomor 2, Juli 2016

\section{Internet}

Wibowo Pajak, Artikel Pajak untuk Bendahara Pemerintah, http://www.wibowopajak.com/2012/01/pajak-untuk-bendahara-pemerintah.html, 2018

Sriwijaya Pos, Empat Bendahara Gaji di Pemkot Pagaralam Terbukti Korupsi Divonis Satu hingga Tiga Tahun Penjara, palembang.tribunews, 2017 diakses tanggal 11 September 2018

\section{Legislations}

Al-qur'an, Tafsir Al-Usyr Al-Akhir, Cetakan IV

Undang-Undang Nomor 31 Tahun 1999 tentang Tindak Pidana Korupsi

Undang-Undang Nomor 20 Tahun 2001 tentang Tindak Pidana Korupsi 
Undang-Undang Nomor 36 Tahun 2008 tentang Pajak Penghasilan

Undang-Undang Nomor 23 Tahun 2011 tentang Pengelolaan Zakat

Peraturan Menteri Keuangan Nomor 162/PMK. 05/2013 Tentang Kedudukan dan Tanggung Jawab Bendahara pada Satuan Kerja Pengelola Anggaran Pendapatan dan Belanja Negara

Peraturan Presiden Republik Indonesia Nomor 192 Tahun 2014 Tentang Badan Pengawasan Keuangan dan Pembangunan (BPKP)

Peraturan Menteri Agama Republik Indonesia, Nomor 18 Tahun 2016 tentang Organisasi dan Tata Kerja Sekretariat Badan Amil Zakat Nasional, Sekretariat BAZNAS 